\title{
Colonic Mucosal Pseudolipomatosis: Diagnosis and Etiology
}

\author{
Bahaa Bseiso, Hussain Issa*, Sami Almomen, Shahad M AlGhamdi, Fatma Alabdrabnabi and Ahmed H Al-Salem \\ ${ }^{1}$ Department of Internal Medicine, King Fahad Specialist Hospital, Saudi Arabia
}

Submission: December 15, 2016; Published: January 25, 2017

"Corresponding author: Hussain Issa, Department of Internal Medicine, Gastroenterology division, King Fahad Specialist Hospital, Dammam, P.O. Box 61015, Qatif 31911, Saudi Arabia, Email: hussain31911@yahoo.com

\begin{abstract}
Background: Colonic pseudolipomatosis is a rare condition and its pathogenesis is still not well-known. Several mechanisms were proposed to explain its pathogenesis. This report describes and discuss colonic pseudolipomatosis incidentally found in a series of 8 patients undergoing routine colonoscopy during a 5 days period.
\end{abstract}

Methods: During a 5-days period (16-20 August 2014), we performed 25 colonoscopies and noticed the sudden appearance of colonic pseudolipomatosis in eight of them.

Results: All underwent routine colonoscopy and found to have sudden appearance of instantaneous white blanching during colonoscopy. These lesions were either seen during insertion or withdrawal of the colonoscope. Biopsy specimen was taken from all and the biopsies showed colonic pseudolipomatosis. The indications for colonoscopy and colonoscopic findings are shown in table 1 . The sudden appearance of this cluster of cases stimulated us to investigate and look for a possible etiology including the help of the central sterile services department (CSSD). We found that the automated endoscope disinfectant machine was not functioning during this week period and the scopes disinfection was done manually. The disinfectant used contained hydrogen peroxide.

Mucosal colonic pseudolipomatosis is a rare colonoscopic finding with distinct endoscopic and histological findings. It is a benign and selflimiting condition. The exact etiology of colonic pseudolipomatosis is not known. We like others feel that endoscopic chemical disinfectant with hydrogen peroxide is important in the pathogenesis of colonic pseudolipomatosis rather than air-pressure related mechanical injury during colonoscopy. Awareness of this is important as colonic pseudolipomatosis may be confused with other pathological conditions. Endoscopists unfamiliar with this condition must keep this in mind as it is self-limiting and biopsies will confirm the diagnosis.

Keywords: Mucosal colonic pseudolipomatosis; Colonoscopy; Etiology; Chemical disinfectant

\section{Introduction}

Colonic pseudolipomatosis is a rare condition and its pathogenesis is still not well-known. Several mechanisms were proposed to explain its pathogenesis. These include mechanical traumatic injury to the colonic mucosa during colonoscopy, intramucosal air or chemical injury by disinfectant [1-5]. This report describes and discusses colonic pseudolipomatosis incidentally found in a series of 8 patients undergoing routine colonoscopy during a one week period. The endoscopic pattern and pathogenesis are discussed in this regard. Awareness of this is important as these lesions can be confused with other pathological conditions.

\section{Patients methods and results}

During a 5-days period (16-20 August 2014), we performed 25 colonoscopies and noticed the sudden appearance of colonic pseudolipomatosis in eight of our patients (Figures 1-6). All of them underwent routine colonoscopy and were found to have a sudden appearance of instantaneous white blanching during colonoscopy. These cases were done by three different gastroenterologists. These lesions were either seen during insertion or withdrawal of the colonoscope. Biopsy specimen was taken from all these lesions. In all, the biopsy showed colonic pseudolipomatosis. The biopsies sections showed colonic 
mucosa with no significant inflammation. The lamina propria contained numerous empty spaces which resemble adipose tissue. These vacuoles are negative for CD34 and D2-40 (vascular and lymphatic markers) and for S-100 protein (fat marker). The features are consistent with colonic mucosal pseudolipomatosis. No microorganisms or parasites are seen. The indications for colonoscopy and colonoscopic findings are shown in Table 1.

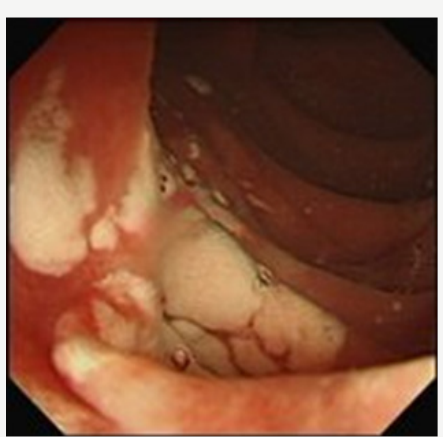

Figure 1

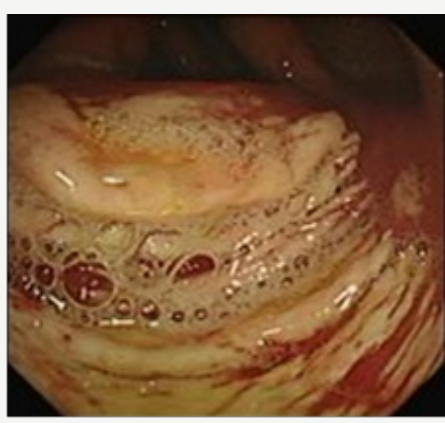

Figure 4

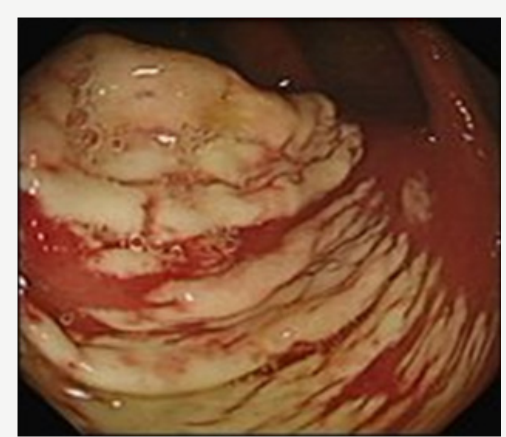

Figure 2

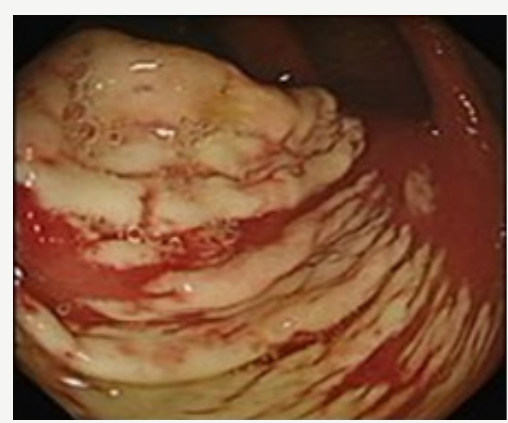

Figure 5

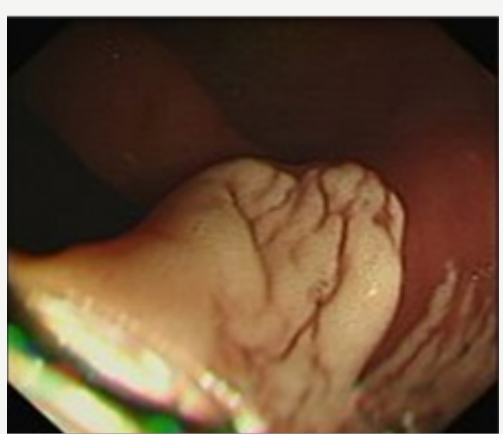

Figure 3

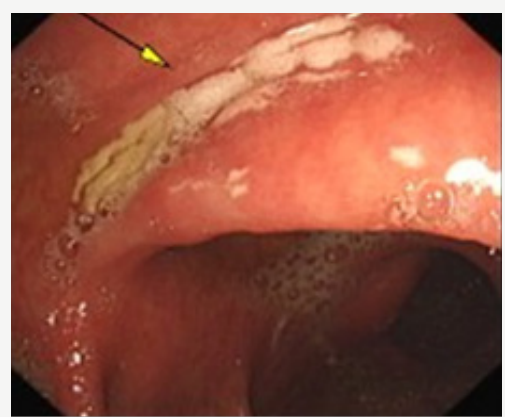

Figure 6

Figure 1-6: Colonoscopic findings of patients with colonic mucosal pseudolipomatosis. Note the variable extent and size of these lesions in different patients.

Table 1: Clinical features and colonoscopic findings in eight patients with Colonic pseudolipomatosis.

\begin{tabular}{|c|c|c|c|}
\hline No. & Age And Sex & $\begin{array}{c}\text { Indication for } \\
\text { Colonoscopy }\end{array}$ & Colonoscopic Findings \\
\hline 1 & 61 Y Female & Screening colonoscopy & White adherent patches in transverse colon \\
\hline 2 & 34 Y Male & Weight loss & Snow white patches distal to cecum \\
\hline 3 & 52 Y Male & Weight loss & Snow white patches at sigmoid colon \\
\hline 4 & 28 Y Male & Chronic abdominal pain & $\begin{array}{c}\text { Large segment of layers of snow white patches at proximal } \\
\text { transverse colon }\end{array}$ \\
\hline 5 & 56 Y Female & Colonic polyps & Spots of snow white patches at rectum and sigmoid colon \\
\hline 6 & 37 Y Female & Sigmoid tumor & White adherent patches at sigmoid colon \\
\hline 8 & 58 Y Male & Screening colonoscopy & White adherent patches at rectum and sigmoid colon \\
\hline & 49 Y Male & Post-resection of & White adherent patches at rectum \\
\hline
\end{tabular}

Following colonoscopy all patients were asymptomatic, and during follow up post endoscopy none of them reported any symptoms or complications. The sudden appearance of this cluster of cases stimulated us to investigate and look for a possible etiology including the help of the central sterile services department (CSSD). We found that the automated endoscope disinfectant machine was not functioning during this week period and the scopes disinfection was done manually. The disinfectant used contained hydrogen peroxide.

\section{Discussion}

Mucosal colonic pseudolipomatosis is a rare colonoscopic finding. The term "colonic pseudolipomatosis" was proposed by Snover et al. [1] in 1985 and was defined as being microscopically 
similar to mucosal lipomatosis but not composed of adipocytes. It is a benign condition with distinct endoscopic and histologic findings and most likely caused by intramucosal air [2]. It is transient and self-limiting condition. The endoscopic appearance of colonic pseudolipomatosis is very characteristic and physicians should be aware of this as it may be confused with other pathological conditions such as pseudomembranous colitis, colonic lipomatosis, or malakoplakia. These lesions appear as slightly elevated mucosal, whitish adherent plaques. They are often multiple and sometimes confluent. They may be small in size measuring few millimeters or extend to measure $4-5 \mathrm{~cm}$. These whitish plaques may be preceded by the appearance of whitish foamy fluid. They can be found in any part of the colon and the right and left colon are affected equally $[2,3]$. Pathologically, these plaques are similar to fat but are characterized by the presence of intramucosal gas trapped empty spaces in the lamina propria. Although they resemble fat, they however differ from lipomatosis by the absence of lipids, which can be verified by fat-specific stains. Because of this gross and microscopic similarity to fat, these lesions are referred to as pseudolipomatosis $[2,3,6,7]$.

The incidence of mucosal colonic pseudolipomatosis is variable in different endoscopy unit ranging from $0.3-1.7 \%$. It was difficult to estimate the incidence in our unit as we see this condition rarely. We were surprised by the sudden appearance of a cluster of eight cases over a short period of one week.

The etiology and pathogenesis of this disorder are controversial. A number of different pathogenetic mechanisms have been hypothesized for this condition, including intramucosal penetration of air by mechanical injury during insufflation, biopsy, or other procedures [2,3]. Others suggested that mucosal colonic pseudolipomatosis is secondary to chemical injury by disinfectants, particularly hydrogen peroxide $[4,5]$. This was the case in our series. Their sudden appearance stimulated us to investigate and look for a possible etiology. We like others think that the use of hydrogen as a disinfectant contributed to the appearance of colonic pseudolipomatosis in our patients.

\section{Conclusion}

Colonic pseudolipomatosis is a rare lesion with distinct endoscopicand histological findings. Itis a benign and self-limiting condition. The exact etiology of colonic pseudolipomatosis is not known. We like others feel that endoscopic chemical disinfectant with hydrogen peroxide is important in the pathogenesis of colonic pseudolipomatosis rather than air-pressure related mechanical injury during colonoscopy. Awareness of this is important as colonic pseudolipomatosis may be confused with other pathological conditions such as pseudo membranous colitis, colonic lipomatosis, or malakoplakia. Endoscopists unfamiliar with this condition must keep this in mind as it selflimiting and biopsies will confirm the diagnosis.

\section{References}

1. Snover DC, Sandstad J, Hutton S (1985) Mucosal pseudolipomatosis of the colon. Am J ClinPathol 84(5): 575-580.

2. Waring JP, Manne RK, Wadas DD, Sanowski RA (1989) Mucosal pseudolipomatosis: An air pressure-related colonoscopy complication. GastrointestEndosc 35(2): 93-94.

3. Kim SJ, Baek IH (2012) Colonic mucosal pseudolipomatosis: Disinfectant colitis? GastroenterolNurs 35(3): 208-213.

4. Cammarota G, Cesaro P, Cazzato A, Fedeli P, Riccioni ME, et al.(2007) Hydrogen peroxide-related colitis (previously known as "pseudolipomatosis"): a series of cases occurring in an epidemic pattern. Endoscopy 39(10): 916-919.

5. Lapeyre B (2005) The 'frost sign' and the 'snow white sign': Intramucosal air injection or peroxide colitis? Endoscopy 37(7): 679.

6. Brevet M, Chatelain D, Bartoli E, Geslin G, Delcenserie R, et al. (2006) Colonic pseudolipomatosis: clinical, endoscopical and pathological features in nine cases. GastroenterolClinBiol 30(1): 9-13.

7. Jonas G, Mahoney A, Murray J, Gertler S (1988) Chemical colitis due to endoscope cleaning solutions: A mimic of pseudomembranous colitis. Gastroenterology 95(5): 1403-1408.

This work is licensed under Creative Commons Attribution 4.0 License DOI:10.19080/ARGH.2017.02.555596

\section{Your next submission with Juniper Publishers will reach you the below assets}

- Quality Editorial service

- Swift Peer Review

- Reprints availability

- E-prints Service

- Manuscript Podcast for convenient understanding

- Global attainment for your research

- Manuscript accessibility in different formats

( Pdf, E-pub, Full Text, Audio)

- Unceasing customer service

Track the below URL for one-step submission https://juniperpublishers.com/online-submission.php 